\title{
Epicardial permanent pacemaker implantation via coronary sinus in a patient with mechanical tricuspid valve prosthesis
}

\author{
Mekanik triküspid kapak protezi olan bir hastada koroner sinüs yolu ile \\ kalıcı pacemaker implantasyonu
}

Tolga DEMIR ${ }^{1}$, Filiz KIZILIRMAK², Nurşen TANRIKULU ${ }^{3}$, Fethi KILIÇARSLAN² ${ }^{2}$ Ergun DEMIRSOY ${ }^{1}$

\section{ABSTRACT}

Pacemaker implantation in patients with tricuspid prosthesis is a challenging situation. It is not possible to pass the pacing lead through tricuspid valve in these patients. Therefore, ventricular pacing can be achieved either epicardial or endocardial left ventricular stimulation. For epicardial pacing, lead implantation can be done transvenously via coronary sinus or surgically. In this paper, we present a patient who had complete atrioventricular block (CAVB) following tricuspid valve prosthesis implantation and treated with epicardial pacing via coronary sinus. In patients who develop CAVB after tricuspid valve replacement, can be treated with permanent pacemaker implantation via CS. This technique enables a minimally invasive approach and effective stimulus in patients with inaccessible right ventricle because of the presence of prosthetic tricuspid valve.

Key words: Mechanical tricuspid valve prosthesis, coronary sinus, permanent pacemaker
Öz

Triküspid protezi olan hastalarında pacemaker implantasyonu zor bir durumdur. Bu hastalarda, pacemaker elektrodunu triküspit kapaktan geçirmek olası değildir. Bu nedenle, ventriküler uyarı, ancak epikardiyal veya endokardiyal sol ventriküler stimülasyon ile elde edilebilir. Epikardiyal uyarı için, elektrodun implantasyonu, tranasvenöz yol ile koroner sinüse veya cerrahi yöntemle yapılabilir. Bu makalede, triküspid kapak replasmanı sonrasında gelişen tam kalp bloğunun, koroner sinüs yoluyla epikardiyal stimülasyon elde edilerek tedavi edildiği bir hastayı sunuyoruz. Triküspid kapak replasmanı sonrası tam kalp bloğu gelişen hastalar koroner sinüs yolu ile implante edilen kalıcı kalp pili ile tedavi edilebilirler. Bu teknik, hem minimal invaziv bir yaklaşım hem de protez triküspid kapak nedeniyle sağ ventriküllerine erişilemeyen hastalarda etkili bir uyarı sağlar.

Anahtar kelimeler: Mekanik triküspid kapak protezi; koroner sinüs; kalıcı pacemaker

\section{INTRODUCTION}

Complete atrioventricular block (CAVB) following tricuspid valve surgery is an important complication which requires permanent pacemaker implantation. However, it is not possible to pass the pacing lead through the mechanical tricuspid valve. In these patients epicardial pacemaker implantation via coronary sinus (CS) can be preferred as an alternative method to surgical epicardial pacemaker implantation ${ }^{1-4}$. In this manuscript, we present a patient who had CAVB following mechanical tricuspid valve replacement and treated with epicardial pacing via CS.

\section{CASE REPORT}

A 58-year-old female patient who underwent mitral valve replacement 15 years ago, presented with shortness of breath. Her electrocardiogram (ECG) revealed atrial fibrillation, echocardiographic examination revealed normal LV systolic function, normal mitral mechanic prosthetic valve, severe tricuspid regurgitation and enlargement of the right heart chambers (Figure 1a). Surgical treatment was recommended for severe tricuspid regurgitation. A mechanical prosthesis was implanted. During the surgery, CAVB developed after removal of the aortic cross clamp

Received: 23.01.2016

Accepted: 20.02.2016

${ }^{1}$ Kolan International Hospital, Department of Cardiovascular Surgery, Istanbul, Turkey

${ }^{2}$ Medipol University Hospital, Department of Cardiology, Istanbul, Turkey

${ }^{3}$ Kolan International Hospital, Department of Anesthesiology, Istanbul, Turkey

Yazışma adresi: Tolga Demir, Kolan International Hospital, Department of Cardiovascular Surgery, Istanbul

e-mail: dr.tolgademir@gmail.com 
and the patient was paced by epicardial temporary pacing leads. On the $7^{\text {th }}$ postoperative day, permanent pacemaker implantation was decided due to the persistence of CAVB. (Figure 1b). Due to the presence of a mechanical tricuspid valve, epicardial pacemaker implantation via CS was planned.

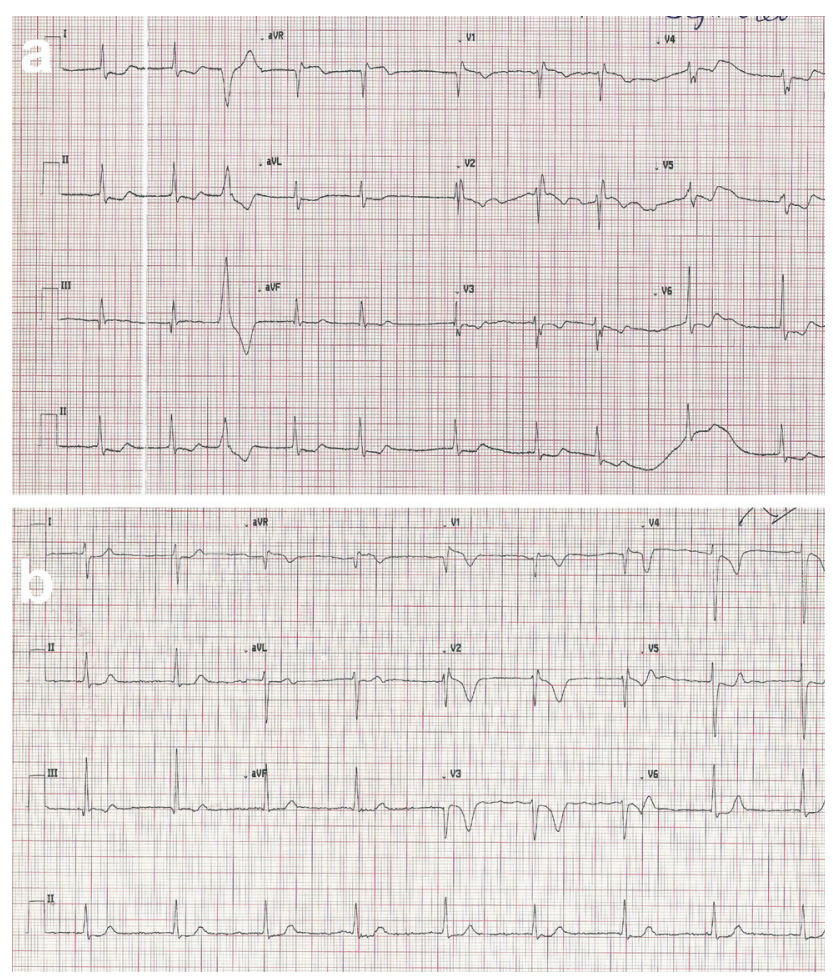

Figure 1. Preoperative 12-lead electrocardiogram (ECG) showing atrial fibrillation (a). Postoperative ECG showing complete atrioventricular block with atrial fibrillation.

A subcutaneous pocket was created at the left pectoral region. Following venous access with modified Seldinger technique the J wire was advanced along inferior vena cava. CS was cannulated and occlusive CS angiogram was performed (Figure 2a). The middle cardiac vein (MCV) was targeted. A 0.014" guidewire was positioned into the MCV and CS pacing lead was advanced over it (Figure $2 \mathrm{~b}$ ). The lead was stable at the apical segment of the MCV. However, at this position because of diaphragmatic stimulation we could not implant the lead to MCV. Then, the posterolateral branch was targeted. A $5 \mathrm{~F}$ coronary angiography catheter was introduced through the CS sheath and posterolateral branch was cannulated. A 0.014 guidewire was advanced through proximal tortous seg-

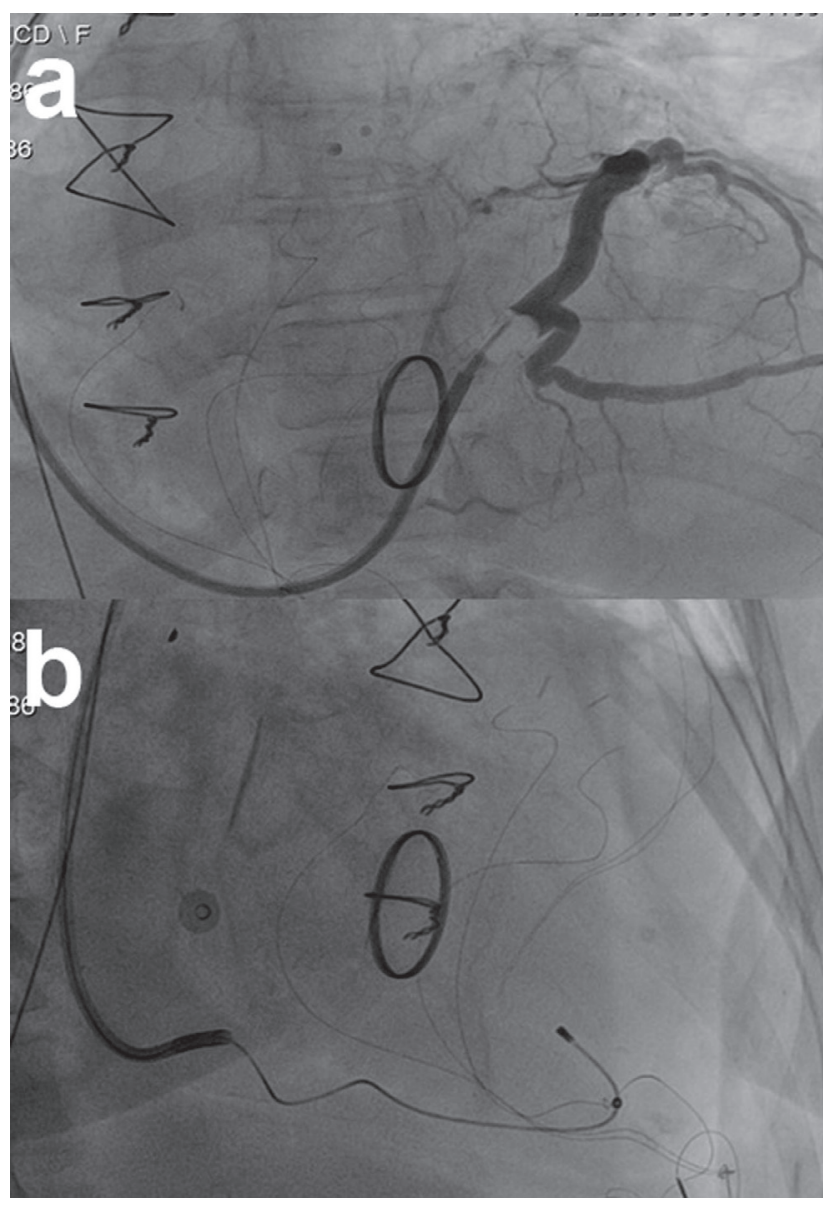

Figure 2. Coronary sinus (CS) angiogram (a), CS pacing lead in the middle cardiac vein (b).

ment. This could be possible with the support of CS sheath and 5-F coronary angiography catheter (Figure 3a). After several attempts we managed to place LV lead in apical region of LV over the guidewire. In this position, pacing threshold, impedance and $R$ wave amplitude were within acceptable ranges and there was no diaphragmatic stimulation (threshold: 0,5 V, Impedance: 780 ohms, R wave: $14 \mathrm{mV}$ ). The lead was connected to pacemaker generator (Medtronic RELIA) (Figure 3b). Postprocedural ECG revealed pacemaker rhythm with right bundle branch morphology. The patient was discharged two days after implantation without any complication. At the follow- up exam, fluoroscopy revealed stable lead position and all pacemaker functions were normal with acceptable interrogation measurements. 


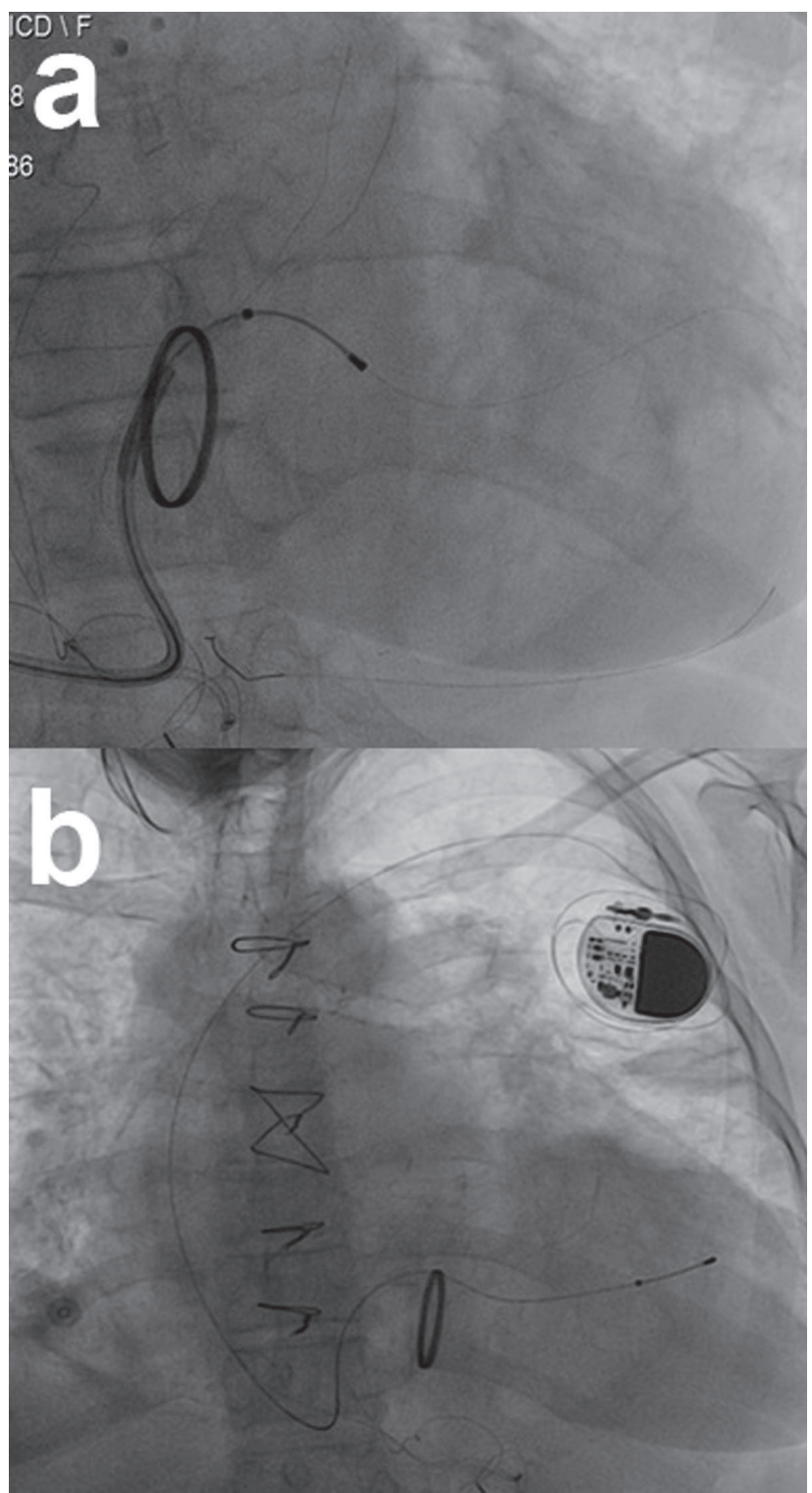

Figure 3. Coronary sinus (CS) pacing lead advanced through posterolateral brunch with support of CS sheath and $5 \mathrm{~F}$ coronary angiography catheter (a), CS pacing lead positioned into posterolateral brunch and connected to pacemaker generator (b).

\section{DISCUSSION}

CAVB following tricuspid prosthesis valve surgery is a common complication mostly related to valve sutures on the septal leaflet near the AV node. A limited number of studies have shown that the need of pacemakers after a tricuspid valve surgery during the early perioperative phase is higher (in $13 \%$ to $28 \%$ of the cases), than other valve interventions 5 . Pace- maker implantation in these patients is troublesome since it is impossible to reach right ventricle. Epicardial pacing (either surgically or via CS) or endocardial LV pacing are the alternative options. Due to preexisting mitral valve prosthesis, LV endocardial pacing was not possible in our patient. Also because of the history of two cardiac surgeries she was not a good candidate for surgical epicardial pacing. Therefore we decided to perform pacemaker implantation via CS. However, if pacing via CS could not be achieved, we have planned surgical epicardial pacing as an alternative treatment option.

Several case reports have been published on epicardial permanent pacemaker implantation via CS in patients with tricuspid valve prostheses ${ }^{3,4}$. In parallel with the frequent use of cardiac resynchronization therapy, the number of pacemacer implantations increased, and permanent pacing via CS have became a viable option in these patients. However, variations in CS anatomy, diaphragmatic stimulation and inability to detect appropriate pacing threshold may sometimes make CS lead implantation impossible. In our case, we had to change position of the lead due to diaphragmatic stimulation in MCV. In patients who underwent surgery for tricuspid valve disease CS distortion and dilation along with dilated right heart chambers may further complicate lead implantation in $\mathrm{CS}$.

Lead dislodgement is an important issue for CS lead implantation. Pacemaker dislocation in a pacemaker dependent patient with total AV block may lead to pacemaker dysfunction which can result in mortal consequences. Therefore, lead stability is crucial in these patients. In our patient, although the tortuosity of the targeted side branch made the implantation difficult, it has provided a good stability. At the follow up exam, functions of the pacemaker were normal. There are leads with active fixation capability which are developed to increase CS lead stability. However, we did not prefer those leads because it would be difficult to advance leads into posterolateral branch of CS due to angled and tortuous anatomy. 
Permanent pacemaker implantation in the right ventricle causes left bundle branch block in ECG after the procedure. In these patients, right bundle branch morphology after permanent pacemaker implantation may be a sign for lead malposition. However, it is an expected and normal ECG finding in patients undergoing permanent pacemaker implantations via CS lead.

In conclusion, patients who develop CAVB after tricuspid valve replacement, can be treated with permanent pacemaker implantation via CS. This technique enables a minimally invasive approach and effective stimulus in patients with inaccessible right ventricle due to the presence of prosthetic tricuspid valve.

\section{REFERENCES}

1. Grimard C, Clémenty N, Fauchier L, Babuty D. Ventricular pacing through coronary sinus in patients with tricuspid prosthesis. Ann Thorac Surg 2010;89:e51-2. http://dx.doi.org/10.1016/j.athoracsur.2010.03.084

2. Demir AD, Sen N, Erbay AR, Atak R. An effective and safe alternative to epicardial pacemaker placement for permanent pacemaker implantation in a patient with mechanical tricuspid valve: stimulation of the left ventricle through the coronary sinus. Turk Kardiyol Dern Ars 2011;39:244-7. http://dx.doi.org/10.5543/tkda.2011.01322

3. Herre JM, Bullaboy CA, Derkac WM, Dow MT. Permanent transvenous dual-chamber pacing using the coronary sinus in a patient with a mechanical prosthetic tricuspid valve. $P e-$ diatr Cardiol 2004;25:65-6. http://dx.doi.org/10.1007/s00246-003-0493-4

4. Vijayakumar M, Kamath P, Pai PG. Permanent pacing in a patient with tricuspid prosthesis-widening therapeutic use of coronary sinus. Indian Heart J 2013;65:611-3. http://dx.doi.org/10.1016/j.ihj.2013.08.012

5. Jokinen JJ, Turpeinen AK, Pitkänen O, Hippeläinen MJ, Hartikainen JE. Pacemaker therapy after tricuspid valve operations: implications on mortality, morbidity, and quality of life. Ann Thorac Surg 2009;87:1806-14. http://dx.doi.org/10.1016/j.athoracsur.2009.03.048 